\title{
Methodiek schoolverlatersinformatiesysteem 1999
}

Citation for published version (APA):

Potma, L., \& van der Kolk, P. (2000). Methodiek schoolverlatersinformatiesysteem 1999.

Researchcentrum voor Onderwijs en Arbeidsmarkt, Faculteit der Economische Wetenschappen. ROA Working Papers No. 9 https://doi.org/10.26481/umarow.2000009

Document status and date:

Published: 01/01/2000

DOI:

10.26481/umarow.2000009

Document Version:

Publisher's PDF, also known as Version of record

\section{Please check the document version of this publication:}

- A submitted manuscript is the version of the article upon submission and before peer-review. There can be important differences between the submitted version and the official published version of record.

People interested in the research are advised to contact the author for the final version of the publication, or visit the DOI to the publisher's website.

- The final author version and the galley proof are versions of the publication after peer review.

- The final published version features the final layout of the paper including the volume, issue and page numbers.

Link to publication

\footnotetext{
General rights rights.

- You may freely distribute the URL identifying the publication in the public portal. please follow below link for the End User Agreement:

www.umlib.nl/taverne-license

Take down policy

If you believe that this document breaches copyright please contact us at:

repository@maastrichtuniversity.nl

providing details and we will investigate your claim.
}

Copyright and moral rights for the publications made accessible in the public portal are retained by the authors and/or other copyright owners and it is a condition of accessing publications that users recognise and abide by the legal requirements associated with these

- Users may download and print one copy of any publication from the public portal for the purpose of private study or research.

- You may not further distribute the material or use it for any profit-making activity or commercial gain

If the publication is distributed under the terms of Article $25 \mathrm{fa}$ of the Dutch Copyright Act, indicated by the "Taverne" license above, 


\section{Methodiek Schoolverlatersinformatiesysteem 1999}

ROA-W-2000/9

Lia Potma en Paul van der Kolk

\section{Researchcentrum voor Onderwijs en Arbeidsmarkt}

Faculteit der Economische Wetenschappen en Bedrijfskunde Universiteit Maastricht

Maastricht, december 2000 
ISBN 90-5321-306-6

Sec00214/LP 


\section{Inhoud}

Pagina

Voorwoord

1 Inleiding 1

2 Schoolverlatersonderzoeken 1

3 Herziening van de competentie-items in de vragenlijst 3

4 Dataverwerking en weging 5

5 Dekkingsgraad en respons $\quad 10$

6 Non-respons 17

7 Besluit 23

Literatuur 23

Appendix A: Kernvragenlijst $\quad 25$ 



\section{Voorwoord}

Dit werkdocument gaat in op de methodiek die in het uitvoeringsjaar 1999 is gehanteerd binnen het schoolverlatersonderzoek zoals dat door het ROA wordt uitgevoerd. Dit betreft de enquêtes Registratie van Uitstroom en Bestemming van Schoolverlaters (RUBS), HBO-Monitor en WOMonitor. Sinds 1996 is het ROA-schoolverlatersonderzoek in vergaande mate geï ntegreerd. Hierdoor is een vergelijkbaar systeem ontstaan, het Schoolverlatersinformatiesysteem (SIS) genoemd, met gegevens over schoolverlaters uit vrijwel het gehele secundair en tertiair onderwijs. In het kader van het onderzoek binnen dit informatiesysteem is onder andere de statistische bijlage van Schoolverlaters tussen onderwijs en arbeidsmarkt 1999 gepubliceerd. Daarnaast zijn er nog twee specifieke rapportages verschenen namelijk, een rapport over de arbeidsmarktpositie van de afgestudeerden van het HBO en een rapport over de arbeidsmarktpositie van afgestudeerden van het kunstvakonderwijs. De lerarenopleidingen zullen in een aparte rapportage worden behandeld. Tevens zullen de belangrijkste resultaten van de WO-Monitor in een landelijke rapportage worden gepresenteerd.

Het Schoolverlatersinformatiesysteem wordt financieel mogelijk gemaakt door de Ministeries van Onderwijs, Cultuur en Wetenschappen, Sociale Zaken en Werkgelegenheid en Landbouw, Natuurbeheer en Visserij, het Expertisecentrum voor Loopbaanvraagstukken LDC, de HBORaad, de VSNU en de deelnemende onderwijsinstellingen. Bij de uitvoering van het onderzoek werkt het ROA samen met DESAN Marktonderzoek b.v. te Amsterdam en STOAS Onderzoek te Wageningen. Binnen het ROA is de projectleiding van het Schoolverlatersinformatiesysteem in handen van dr. R.K.W. van der Velden en dr. M.H.J. Wolbers. Dit werkdocument is samengesteld door E.J. Potma en P.J.E.G. van der Kolk. Drs. J. van Loo heeft paragraaf 3 geschreven. Verder hebben aan het Schoolverlatersinformatiesysteem 1999 meegewerkt dr. J.P. Allen, drs. T.G. Huijgen, drs. G.W.M. Ramaekers en E.M.H.P. Soudant (allen werkzaam bij ROA), alsmede drs. M. van Alphen, drs. H. van Dongen, drs. ing. K.J. Pagrach, ing. J.J. Rutjes en drs. R. Tjemmes (allen werkzaam bij DESAN Marktonderzoek). 


\section{Inleiding}

Door het ROA worden jaarlijks drie grootschalige schoolverlatersonderzoeken uitgevoerd. In de eerste plaats betreft dit een onderzoek onder de schoolverlaters van het algemeen voortgezet onderwijs (AVO), het voorbereidend beroepsonderwijs (VBO) ${ }^{1}$, de beroepsopleidende leerweg (BOL) en de beroepsbegeleidende leerweg (BBL) van het secundair beroepsonderwijs aan de hand van de enquête Registratie van Uitstroom en Bestemming van Schoolverlaters (RUBS). In de tweede plaats is dit een onderzoek onder de afgestudeerden van het Hoger Beroepsonderwijs (HBO) via de HBO-Monitor. In de derde plaats wordt onderzoek verricht onder de afgestudeerden van de universiteiten (WO-Monitor). Deze schoolverlatersonderzoeken vormen de basis voor een aantal landelijke publicaties, zoals de recent verschenen statistische bijlage Schoolverlaters tussen onderwijs en arbeidsmarkt 1999 en de rapporten De arbeidsmarktpositie van afgestudeerden van het hoger beroepsonderwijs; HBO-Monitor 1999 en De arbeidsmarktpositie van afgestudeerden van het Kunstenonderwijs; Kunsten-Monitor 1999.

Dit werkdocument vormt een methodologische aanvulling op deze reeds verschenen en nog te verschijnen rapporten. Er zal met name worden ingegaan op de gehanteerde methodiek, de respons en het uitgevoerde non-responsonderzoek. De opzet van de rest van dit werkdocument is als volgt. Allereerst wordt in paragraaf 2 een uiteenzetting gegeven over het doel en de opzet van de schoolverlatersonderzoeken. In paragraaf 3 wordt dieper ingegaan op de vraagstelling die is gehanteerd met betrekking tot de competentie-items in de vragenlijst. Vervolgens wordt in paragraaf 4 ingegaan op de dataverwerking en de weging van de gegevens. In paragraaf 5 wordt daarna een overzicht gegeven van de dekkingsgraad en de respons. Paragraaf 6 bevat een verslag van het non-responsonderzoek en in paragraaf 7 wordt dit werkdocument ten slotte kort samengevat.

\section{Schoolverlatersonderzoeken}

Doel

De schoolverlatersenquêtes van het ROA zijn gericht op het monitoren en analyseren van de bestemming van (gediplomeerde) schoolverlaters in het vervolgonderwijs en op de arbeidsmarkt. Daarbij kunnen twee componenten worden onderscheiden: een toepassingscomponent en een onderzoekscomponent. De toepassingscomponent richt zich op de zorg van individuele onderwijsinstellingen voor de onderwijskwaliteit en de afstemming van het onderwijs op de behoeften van de arbeidsmarkt. Daarvoor worden zogenaamde instellingsrapportages opgesteld waarin de onderwijsinstellingen informatie krijgen over hun eigen afgestudeerden, waar relevant afgezet tegen het landelijke beeld. Hiermee kunnen management, studierichtingsleiders en decanaat een indruk krijgen van het externe rendement van hun opleidingen.

De onderzoekscomponent van het schoolverlatersonderzoek, aangeduid als het Schoolverlatersinformatiesysteem (SIS), heeft als doel het analyseren van het doorstroompatroon van schoolverlaters naar vervolgonderwijs en het transitieproces van school naar werk. De resultaten

1. Inclusief het individueel voorbereidend beroepsonderwijs (IVBO). 
hiervan worden onder meer gepubliceerd via algemeen toegankelijke landelijke rapportages. Hierin ligt het accent op (de ontwikkelingen in) het intredeproces van schoolverlaters, de kansen op het vinden van werk, de kwaliteit van het werk en het keuzegedrag van schoolverlaters ten aanzien van mogelijke vervolgopleidingen en de kwaliteit van de aansluiting die daarbij wordt ondervonden.

\section{Opzet}

Zoals is aangegeven vormt een drietal schoolverlatersonderzoeken (RUBS, HBO-Monitor en WO-Monitor) de basis van het Schoolverlatersinformatiesysteem. Voor al deze schoolverlatersonderzoeken geldt dat onderwijsinstellingen zelf aangeven of zij met (een deel van) hun schoolverlaters of afgestudeerden willen deelnemen. De RUBS-enquête wordt bij de scholen aangeboden onder verantwoordelijkheid van het LDC. De HBO-Monitor en de Kunstenmonitor worden bij de hogescholen aangeboden onder auspiciën van de HBO-Raad. De WO-Monitor vindt in VSNU-verband plaats. Het ROA draagt zorg voor de uitvoering van de WO-Monitor voor negen universiteiten en heeft daarnaast de landelijke coördinatie. De Rijksuniversiteit Groningen, de Katholieke Universiteit Nijmegen, de Universiteit Twente en de Universiteit Utrecht hebben de enquête zelf uitgevoerd. Ook de gegevens van deze 'lokale' uitvoerders zijn opgenomen in het Schoolverlatersinformatiesysteem. Binnen het agrarisch onderwijs worden de resultaten van de onderzoeken aangeboden door STOAS Onderzoek te Wageningen.

Door bovengenoemde werkwijze is er geen sprake van een aselecte steekproef. Met name bij de RUBS-enquête is de dekkingsgraad niet altijd even hoog (zie paragraaf 4). Mochten er 'witte vlekken' in de deelname aan RUBS ontstaan - zowel naar opleidingsrichting als regio - dan wordt hier een aanvullende steekproef getrokken. In 1999 was deze aanvullende steekproef echter niet nodig.

Sinds het uitvoeringsjaar 1996 wordt het schoolverlatersonderzoek van het ROA uitgevoerd volgens een geï ntegreerd model, waarbij één meetmoment en één kernvragenlijst wordt onderscheiden. In de praktijk betekent dit dat in de periode oktober-december 1999 ruim 120.000 schoolverlaters en afgestudeerden van het school-/studiejaar 1997/1998 zijn benaderd met een schriftelijke vragenlijst. Wanneer schoolverlaters na ruim een maand de vragenlijst nog niet hebben teruggestuurd, wordt een rappel verstuurd.

Hoewel de vragenlijsten in de kern gelijk zijn, is ook in het uitvoeringsjaar 1999 enige variatie aan vragen tussen de verschillende vragenlijsten. Hiermee wordt recht gedaan aan de verschillen die er tussen de diverse onderwijsniveaus of -sectoren bestaan.

Binnen RUBS zijn aparte lijsten gebruikt voor de schoolverlaters van MAVO, HAVO/VWO, IVBO, VBO en MBO. Bovendien zijn voor het agrarisch onderwijs op zowel (I)VBO- als MBO-niveau specifieke vragenlijsten gebruikt. Verder zijn de schoolverlaters van het AVO die de arbeidsmarkt hebben betreden telefonisch ondervraagd over hun arbeidsmarktpositie. Binnen de HBO-Monitor is een aparte vragenlijst opgesteld voor de afgestudeerden van het landbouwonderwijs en het pedagogisch onderwijs. Daarnaast zijn onder de naam Kunsten-Monitor twee specifieke vragenlijsten opgesteld voor afgestudeerden van respectievelijk HBO Beeldende Kunst en Vormgeving en HBO Muziek en Theater. In het kader van de WO-Monitor zijn er, naast de standaard WO-lijst, 
aparte vragenlijsten opgesteld voor het pedagogisch onderwijs en het agrarisch onderwijs (afgestudeerden van de Landbouw Universiteit Wageningen).

Om een hogere respons te bereiken, is onder HBO-afgestudeerden van het kunstonderwijs die de schriftelijke vragenlijst niet hebben teruggestuurd een deel van de vragenlijsten alsnog telefonisch afgenomen. De afgestudeerden van het pedagogisch onderwijs, op HBO-niveau en op WO-niveau, die in eerste instantie niet hebben gereageerd op de schriftelijke enquête zijn eveneens naderhand telefonisch benaderd.

De vragenlijsten van het uitvoeringsjaar 1999 bestaan uit een viertal hoofdonderwerpen: algemeen (geslacht, leeftijd e.d.), onderwijsloopbaan, arbeidsmarktintrede en een thematisch gedeelte $^{2}$. Binnen de vragenlijsten voor het AVO en het VBO ligt de nadruk op de doorstroom naar het vervolgonderwijs en de redenen van eventuele uitval. Tevens wordt in deze vragenlijsten uitgebreid stilgestaan bij de rol van studie- en beroepskeuzebegeleiding. Er wordt slechts in beperkte mate aandacht besteed aan de arbeidsmarktintrede van deze groep schoolverlaters. Binnen het AVO zijn echter wel, zoals gezegd, aan de werkenden aanvullend telefonisch vragen over hun arbeidsmarktpositie gesteld. In de overige vragenlijsten ligt de nadruk juist op het transitieproces van school naar werk en wordt minder vergaand gevraagd naar de doorstroom naar vervolgonderwijs. In het thematisch gedeelte is in 1999 expliciet aandacht besteed aan een herziening van de meting van de competentieverwerving onder schoolverlaters.

\section{Herziening van de competentie-items in de vragenlijst}

Het competentieblok in de vragenlijsten van het Schoolverlaterinformatiesysteem is de laatste jaren uitgegroeid tot een apart vragenblok in de enquête. Vooral omdat er in het verleden telkens nieuwe items zijn toegevoegd is de lijst nogal een belasting geworden voor de respondent. Daarnaast is de tot 1998 gebruikte vraagstelling sterk gericht geweest op kenmerken van de baan door het gebruik van de 'belang'-vraagstelling. De huidige aandacht voor competenties komt echter veel meer voort uit een belangstelling voor individuele eigenschappen die het succes op de arbeidsmarkt verklaren.

Verder is de empirische gebruikswaarde van de competentie-items in het verleden nogal beperkt geweest. Zo blijkt dat de lange competentielijst respondenten niet stimuleerde om variabiliteit in de antwoorden aan te brengen, wat de bruikbaarheid van de resultaten verminderde. Ook nodigde de opzet van het 'aandacht'-gedeelte onvoldoende uit tot een 'trade-off' tussen items die meer aandacht zouden moeten krijgen in het onderwijs en items die minder aandacht zouden behoeven. Uit empirische analyses bleek dat de meeste respondenten aangaven dat er voor ieder aspect evenveel dan wel meer aandacht nodig was; een resultaat dat weinig mogelijkheden biedt tot een zinvolle interpretatie, omdat het eenvoudigweg niet mogelijk is om aan een groot gedeelte van de competenties meer aandacht te geven zonder aan andere aspecten minder aandacht te besteden.

2. Zie bijlage A voor een overzicht van het kerndeel van de vragenlijst. 
Deze tekortkomingen, maar ook de onduidelijkheid rond het begrip competentie zelf in de context van het schoolverlatersonderzoek zijn in 1999 aanleiding geweest tot de vorming van een groep van geï nteresseerde ROA-onderzoekers die zich uitvoerig over de competentiemeting in de vragenlijsten hebben gebogen. In die groep is gewerkt volgens een tweestappenplan. Eerst is op basis van de theoretische literatuur het competentiebegrip gedegen in kaart gebracht. Vervolgens is er op basis van de verkregen inzichten een nieuwe methodologie voor de meting van competenties ontwikkeld. In eerste instantie zijn de veranderingen doorgevoerd in de HBOen WO-vragenlijsten. Hieronder gaan we kort in op de doorgevoerde veranderingen en de overwegingen die daaraan ten grondslag lagen.

\section{Van 29 naar 14 competentie-items}

De eerste verandering die met ingang van 1999 voor de HBO- en WO-vragenlijsten is doorgevoerd betreft het aantal ondervraagde competentie-items. In het verleden is het competentiebegrip altijd benaderd via een aantal aspecten die verdeeld waren in kennis en technieken, vaardigheden, en houdingsaspecten. Uit correlatie-analyses is gebleken dat veel van deze aspecten sterk samenhangen en daarmee nauwelijks van elkaar te onderscheiden zijn. Om zowel beter afgebakende competenties te verkrijgen en tegelijkertijd de belasting voor de respondenten te verminderen is er voor gekozen de vragenlijst drastisch in te korten en het competentiebegrip op een holistische wijze te beschouwen. Dit laatste houdt in dat de competenties gezien worden als samengesteld uit kennis, vaardigheden en attitudes (Straetmans, 1998). Door deze benadering toe te passen en daarnaast de literatuur rond sleutelvaardigheden te bestuderen (zie bijvoorbeeld Tribe, 1996) bleek het mogelijk de lijst van 29 aspecten zoals die in 1998 gebruikt werd in te korten tot een lijst van 14 items.

\section{Van de 'belang' naar de 'gebruik' benadering}

De eerste vraag over competenties was tot en met de meting van 1998 geformuleerd in termen van het belang van de competenties voor het uitvoeren van de baan. Met ingang van 1999 is gekozen voor een vraag die het gebruik van de verschillende items meet. Zo ligt de nadruk niet meer op kenmerken van de baan, maar op kenmerken van de respondent. Het op een dergelijke manier meten van competenties wordt in de literatuur ook wel aangeduid als het meten van 'competences-in-use'. Dit houdt in dat competenties worden gemeten als interacties tussen de baan en het individu (zie ook Ellström, 1998). Met de 'gebruik' formulering wordt ook tegemoetgekomen aan het holistische competentiebegrip: het gebruik van competenties veronderstelt immers impliciet het aanwenden van de benodigde kennis, het gebruiken van de daarmee samenhangende vaardigheden en het aannemen van een attitude die vereist is om een goed resultaat te bereiken.

\section{Van de 'aandachtbenadering' naar een top-3}

In het verleden is voor ieder competentie-item gevraagd of deze volgens de respondent meer, minder of evenveel aandacht zou moeten krijgen in de opleiding die ze gevolgd hebben. Deze benadering heeft, zo bleek uit empirische analyses, onvoldoende het karakter van een 'trade-off', dat wil zeggen een afweging tussen competenties die meer aandacht behoeven en competenties die juist minder aan de orde zouden moeten komen in de opleiding. Daarom is er nu voor 
gekozen de respondenten te laten kiezen voor drie competenties waarvan ze vinden dat deze onvoldoende in het onderwijs aan de orde zijn geweest en drie competenties waarvan ze vinden dat deze juist wel voldoende aan bod zijn gekomen.

\section{De introductie van de 'leerbron' van competenties}

Uit de recente literatuur rond competentieverwerving blijkt dat mensen in de huidige arbeidsmarkt hun benodigde vaardigheden vaak tijdens het werk leren. Deze vorm van leren is in een arbeidsmarkt die continu verandert, onontbeerlijk. Om een beeld te krijgen van de competenties die op deze manier verworven worden en tegelijkertijd duidelijk te maken welke competenties juist wel primair in het onderwijs geleerd worden, is met ingang van 1999 voor iedere competentie gepeild naar de belangrijkste leerbron. Naast de wetenschappelijke waarde van dergelijke informatie kan ook het beleid profiteren van dergelijke inzichten. Wanneer bijvoorbeeld blijkt dat een bepaalde competentie hoofdzakelijk tijdens het werk wordt geleerd, kan het wellicht verstandig zijn de middelen die in het onderwijs aan het leren van die competentie worden besteed te verschuiven naar competenties die wel hoofdzakelijk in het onderwijs worden geleerd maar waaraan volgens een groot gedeelte van de respondenten te weinig aandacht wordt besteed.

\section{Enkele empirische vergelijkingen tussen de oude en de nieuwe meetmethode}

Wanneer de competentie-items in de vragenlijsten van 1998 en 1999 met elkaar vergeleken worden, blijkt dat de winst van de aanpassingen die zijn toegepast duidelijk zichtbaar zijn. Ten eerste blijkt de nieuwe meetmethodiek beter in het afbakenen van competenties. Daarnaast is met de top-3 methode bereikt dat de spreiding in de antwoorden veel groter is geworden, en dat er nu een duidelijke trade-off beschikbaar is, die met de vorige meetmethode ontbrak. Ten slotte blijkt ook dat de voorspellende waarde van competenties voor de arbeidsmarktpositie van schoolverlaters (in termen van beloning) aanmerkelijk is verbeterd.

\section{Dataverwerking en weging}

Het versturen van alle vragenlijsten, het verzorgen van de rappels, het coderen van open vragen (waaronder vervolgopleiding, beroep, bedrijfssector), de data-entry en de eerste bestandscontroles en correcties worden uitgevoerd door het marktonderzoekbureau DESAN b.v. te Amsterdam. Het ROA voert een datacleaning uit op verwijzingsstructuur en op onderlinge consistenties. Vervolgens worden nieuwe samengestelde variabelen aangemaakt en wordt het bestand gewogen, zodat op basis van de gegevens landelijk representatieve uitspraken gedaan kunnen worden.

\section{Dataverwerking}

De vragenlijsten bevatten voor het merendeel gesloten antwoordcategorieën, waarbij de respondenten kunnen kiezen uit een aantal voorgelegde mogelijkheden. In een beperkt aantal gevallen dienen de schoolverlaters zelf een numerieke waarde in te vullen, bijvoorbeeld bij de kenmerken leeftijd, inkomen en aantal gewerkte uren. Bij enkele vragen wordt gebruik gemaakt van een volledig open vraagstelling, waarbij de schoolverlaters zelf het antwoord op de vraag moeten omschrijven. Dit is met name het geval bij vragen over: 
- soort opleiding (voor- of vervolgopleiding);

- beroep;

- bedrijfssector;

- gemeente (woon- of werkgemeente).

Bij deze vragen worden de alfanumerieke antwoorden van de respondenten gecodeerd volgens vooraf opgestelde classificaties. Voor de opleidingsvragen wordt daarbij gebruik gemaakt van een speciaal voor dit doel door het ROA opgestelde opleidingsclassificatie, waarin alle in Nederland voorkomende (reguliere) opleidingen zijn opgenomen ${ }^{3}$. Beroep en bedrijfssector worden gecodeerd volgens de Standaard Beroepen Classificatie 1992 (SBC '92) en de Standaard Bedrijfsindeling 1993 (SBI '93) van het CBS. Overigens zijn beide classificaties, waar relevant, door het toevoegen van een extra digit verder verbijzonderd. Gemeenten worden gecodeerd volgens de gemeentecodes die door het CBS in het meest recente Plaatsnamenregister worden gehanteerd.

In de data-entry programmatuur worden geen echte correcties op de data doorgevoerd. Wel worden aan elke vraag minimum en maximumgrenzen toegepast om tikfouten te voorkomen. $\mathrm{Na}$ een waarschuwing kunnen deze grenzen wel 'overruled' worden. $\mathrm{Na}$ de data-entry worden de aldus verkregen ruwe gegevens door DESAN onderworpen aan een eerste kwaliteitscontrole. DESAN stelt het onderzoeksbestand samen en controleert op cruciale variabelen zoals uniek casenummer, schoolnummer, opleiding, respons, voltijd/deeltijd opleiding en diplomabezit. Deze variabelen worden onderling en met de variabele 'vragenlijst' op elkaar afgestemd. Bijvoorbeeld: komt een bepaalde (vol- of deeltijd) opleiding voor op die school, is voor deze opleiding de juiste vragenlijst gehanteerd, is de vragenlijst grotendeels (naar waarheid) ingevuld, zijn de afgestudeerden ook gediplomeerd e.d. Na deze eerste controle geeft DESAN het onderzoeksbestand aan het ROA, waar vervolgens de volgende controles en correcties doorgevoerd worden:

1. Controle op variabelen met "anders-categorie": hierin wordt bekeken of er bij de vragen met een antwoordcategorie "anders, namelijk ..." bepaalde overeenkomstige antwoorden kunnen worden onderscheiden zodat vervolgens eventuele nieuwe antwoordcategorieën worden aangemaakt of dat de "anders-categorie" teruggebracht kan worden naar een al bestaande antwoordcategorie.

2. Doorvoeren van de verwijzingsstructuur: zijn er na een verwijzingsvraag minimaal 3 vervolgvragen ingevuld dan wordt het antwoord op de verwijzingsvraag zodanig aangepast dat de verwijzing niet opgevolgd wordt. Dit gebeurt alleen bij verwijzingsvragen met 2 antwoordmogelijkheden, zodat altijd duidelijk is welk antwoord de verwijzing negeert. Zijn er minder dan 3 vervolgvragen dan geldt dat alle vervolgvragen een geldig antwoord moeten hebben. Zodoende garandeert de verwijzingsvraag altijd een juist aantal cases op de vervolgvragen. Verder worden er verschillende codes toegepast op vragen die wel

3. Daarbij is een rechtstreekse koppeling mogelijk met de Standaard Onderwijs Indeling (SOI) van het CBS. 
beantwoord hadden moeten worden, maar wat niet is gebeurd (onbekend) en op vragen die door een verwijzingsvraag niet beantwoord moeten worden (sysmis).

3. Afronding cleaning: tot slot van de cleaning worden de cases die niet bruikbaar zijn uit het bestand verwijderd. Dit zijn onder andere de cases waarvan de afstudeerperiode niet correct is of cases waarvan meerdere cruciale basisvariabelen ontbreken.

$\mathrm{Na}$ de cleaning wordt het onderzoeksbestand uitgebreid met een aantal nieuwe samengestelde variabelen. Dit zijn variabelen die specifiek zijn gedefinieerd en op meerdere basisvariabelen zijn gebaseerd (bijvoorbeeld de variabele beroepsbevolking).

\section{Gecorrigeerde verwijzingsvraag 'betaald werk'}

Door een ogenschijnlijk ongevaarlijke aanpassing in de opmaak van de vragenlijsten van het (I)VBO, BOL en BBL (exclusief landbouw) zijn het afgelopen meetjaar bij de verwijzingsvraag 'betaald werk' twee antwoordcategorieën in plaats van onder elkaar naast elkaar afgedrukt. Hierdoor beantwoordde meer dan de helft van de respondenten deze vraag ten onrechte met 'nee' omdat zij betaald werk associeerden met opleiding in beroepsbegeleidende leerweg (BBL). Gevolg was dat de daaropvolgende vervolgvragen 'betaald werk' niet werden ingevuld.

$\mathrm{Na}$ ontdekking hiervan is allereerst gecontroleerd hoe groot de afwijking van de variabelen is, die afhankelijk zijn van de 'betaald werk' variabelen. De verwijzingsvraag 'betaald werk' is gecontroleerd met de variabele maatschappelijke positie. Respondenten die een maatschappelijke positie hadden van betaald werk of beroepsbegeleidende leerweg (BBL) en die de verwijzingsvraag 'betaald werk' met 'ja' hadden beantwoord, werden via een nieuwe wegingsfactor opgewaardeerd. De mate van opwaardering werd bepaald op basis van het onderzoeksbestand van 1998 (waar bovengenoemde controle eveneens op werd uitgevoerd), zodat de verhouding van 1998 wordt weergegeven in 1999. De invloed van deze nieuwe wegingsfactor bleek op kernvariabelen (vereist opleidingsniveau, inkomen e.d.) minimaal te zijn. De conclusie luidt daarom dat de respondenten die de vervolgvragen 'betaald werk' juist hebben ingevuld (o.b.v. de verwijzing) geen afwijkende groep zijn ten opzichte van de respondenten die deze vervolgvragen 'betaald werk' niet hebben ingevuld. Hierdoor is de nieuwe wegingsfactor uiteindelijk niet toegepast.

Vervolgens is de verwijzingsvraag 'betaald werk' gecorrigeerd, omdat op basis van deze variabele onder andere de beroepsbevolking wordt bepaald. Alleen de antwoorden van de respondenten worden gecorrigeerd, die bij de maatschappelijke positie 'betaald werk' hebben aangegeven en degenen die bij de maatschappelijke positie beroepsbegeleidende leerweg hebben aangegeven, in combinatie met de vraag of ze in de vervolgopleiding betaald werk hebben verricht. In deze gevallen is de verwijzingsvraag 'betaald werk' met 'ja' gecorrigeerd.

Voor het juist bepalen van de beroepsbevolking hebben we ook het huidige aantal uren dat men werkt nodig. Dit is echter één van de vervolgvragen van het vragenblok 'betaald werk' dat ten onrechte niet was ingevuld. Er is daarom verondersteld dat deze groep van respondenten, die betaald werk verrichten, dat meer dan 12 uur per week doen. Zodoende behoren zij tot de groep 
van werkzame personen. Daarna zijn met deze twee correcties op de basisvariabelen de nieuwe samengestelde variabelen opnieuw aangemaakt.

\section{Weging}

De deelname van de scholen aan de schoolverlatersonderzoeken geschiedt zoals gezegd op vrijwillige basis. Hierdoor ontstaat er in de regel een ongelijke spreiding naar opleiding en regio. Ook naar andere kenmerken van de populatie kan er een niet-representatieve verdeling ontstaan. Zo is de respons bij vrouwen in het algemeen hoger dan bij mannen, waardoor vrouwen oververtegenwoordigd zijn in het onderzoeksbestand. Dergelijke omstandigheden leiden ertoe dat het onderzoeksbestand geen landelijke weergave is van de doelgroep. Om toch betrouwbare landelijke gegevens te kunnen presenteren, wordt een weging uitgevoerd op het bestand zoals dat na de dataverwerking is verkregen. Daarbij wordt een zodanige weging uitgevoerd dat de aantallen uiteindelijk corresponderen met de aantallen in de populatie.

Voor de weging wordt gebruik gemaakt van populatiegegevens die beschikbaar zijn op basis van de Integrale Leerlingtelling (ILT) (voor wat betreft het AVO, VBO, BOL en BBL) en het Centraal Register Instellingen Hoger Onderwijs (CRIHO) (betreffende het HBO). Beide databestanden worden beheerd door het Ministerie van Onderwijs, Cultuur en Wetenschappen. De populatiegegevens van HBO Kunst en Cultuur zijn echter niet gebaseerd op de CRIHO-data. Deze bleek niet volledig betrouwbaar voor deze sector. Als populatie is daarom het totale aantal uitgezette vragenlijsten per kunstopleiding gebruikt. Dit is mogelijk omdat van de opleidingen die in de steekproef zitten iedereen benaderd wordt. Ten aanzien van de schoolverlaters van de landbouwopleidingen wordt gebruik gemaakt van overeenkomstige gegevens beschikbaar gesteld door het Ministerie van Landbouw, Natuurbeheer en Visserij. Voor wat betreft de WOopleidingen ten slotte, wordt geen weging maar alleen een ophoging toegepast. De reden hiervoor is dat iedere afgestudeerde van het WO wordt benaderd en er dus geen sprake is van een steekproef.

De ILT 1997/1998 heeft per instelling en per opleiding gegevens beschikbaar over het aantal leerlingen per leerjaar en geslacht ${ }^{4}$. Het CRIHO bevat per instelling en opleiding gegevens over het aantal diploma's, waarbij eveneens een onderverdeling naar geslacht is gemaakt. In principe wordt op het niveau van opleiding $x$ regio $x$ geslacht een weegfactor bepaald die de verhouding aangeeft tussen het populatie-aantal en het aantal respondenten in het onderzoeksbestand. Bij de weging van $\mathrm{HBO}$-opleidingen wordt bovendien een onderscheid gemaakt tussen voltijd- en deeltijdopleidingen.

In principe wordt er dus gewogen op opleiding $x$ voltijd/deeltijd (alleen $\mathrm{HBO}$ ) $\mathrm{x}$ regio $\mathrm{x}$ geslacht. Indien deze resulterende weegfactor groter is dan 3 maal de gemiddelde weegfactor en als bovendien geldt dat het aantal cases dat wordt gewogen kleiner is dan 50, dan wordt het kenmerk geslacht en indien noodzakelijk ook het kenmerk regio buiten beschouwing gelaten. In

4. Helaas zijn gegevens over het aantal gediplomeerden vanwege privacy-redenen tegenwoordig niet meer beschikbaar. Om toch rekening te houden met het rendement van het laatste leerjaar is hiervoor gebruikt gemaakt van gegevens van twee jaar geleden. 
dat geval wordt gewogen op het niveau van opleiding $x$ voltijd/deeltijd (alleen HBO) $x$ regio, respectievelijk opleiding $x$ voltijd/deeltijd (alleen HBO). Voor een aantal opleidingen heeft voorafgaand aan de weging een clustering van opleidingen plaatsgevonden. Op dit hogere clusterniveau wordt vervolgens de weging uitgevoerd. Overigens worden in de schoolverlatersonderzoeken geen landelijke gegevens gepresenteerd wanneer deze betrekking hebben op minder dan 15 respondenten in de steekproef. Tabel 4.1 geeft een overzicht van de aantallen schoolverlaters per opleidingssector vóór en ná de weging. Bij het HBO is daarbij tevens een onderscheid gemaakt naar voltijd en deeltijd.

Tabel 4.1

Aantallen schoolverlaters per opleidingssector zowel voor weging als na weging

\begin{tabular}{|c|c|c|}
\hline Opleidingssector & $\begin{array}{l}\text { Ongewogen } \\
\text { aantal }\end{array}$ & $\begin{array}{c}\text { Gewogen } \\
\text { aantal }\end{array}$ \\
\hline AVO & 5.850 & 99.000 \\
\hline MAVO & 2.134 & 43.700 \\
\hline HAVO & 2.087 & 30.700 \\
\hline VWO & 1.629 & 24.600 \\
\hline VBO & 2.860 & 43.300 \\
\hline IVBO & 639 & 9.000 \\
\hline landbouw & 952 & 3.700 \\
\hline techniek & 507 & 15.100 \\
\hline economie & 330 & 5.400 \\
\hline gezondheidszorg & 432 & 10.100 \\
\hline BOL niveau $1 / 2$ & 946 & 11.400 \\
\hline landbouw & 71 & 300 \\
\hline techniek & 191 & 2.700 \\
\hline economie & 555 & 6.700 \\
\hline gezondheidszorg & 129 & 1.700 \\
\hline BOL niveau $3 / 4$ & 6.945 & 42.100 \\
\hline landbouw & 841 & 3.300 \\
\hline techniek & 1.717 & 10.100 \\
\hline economie & 2.028 & 14.700 \\
\hline gezondheidszorg & 1.030 & 6.300 \\
\hline gedrag en maatschappij & 1.329 & 7.700 \\
\hline BBL niveau $1 / 2$ & 803 & 15.200 \\
\hline techniek & 407 & 8.400 \\
\hline economie & 317 & 5.700 \\
\hline $\begin{array}{l}\text { gezondheidszorg } \\
\text { Tabel } 41 \text { (vervola) }\end{array}$ & 79 & 1.100 \\
\hline
\end{tabular}

Opleidingssector

Ongewogen

aantal

Gewogen

aantal

BBL niveau 3/4

699

323

13.000

techniek

5.100 


$\begin{array}{lrr}\text { economie } & 225 & 1.900 \\ \text { gezondheidszorg } & 118 & 5.300 \\ \text { gedrag en maatschappij } & 33 & 700 \\ \text { HBO voltijd } & 15.135 & 42.000 \\ \text { landbouw } & 751 & 1.600 \\ \text { onderwijs } & 2.047 & 7.400 \\ \text { techniek } & 2.951 & 9.700 \\ \text { economie } & 4.176 & 11.800 \\ \text { gezondheidszorg } & 1.823 & 3.800 \\ \text { gedrag en maatschappij } & 2.293 & 5.300 \\ \text { kunst en cultuur } & 1.094 & 2.400 \\ & & \\ \text { HBO deeltijd } & 2.172 & 9.100 \\ \text { landbouw } & 32 & 100 \\ \text { onderwijs } & 561 & 3.400 \\ \text { techniek } & 142 & 400 \\ \text { economie } & 322 & 1.600 \\ \text { gezondheidszorg } & 350 & 1.300 \\ \text { gedrag en maatschappij } & 644 & 2.100 \\ \text { kunst en cultuur } & 121 & 200 \\ & & \\ \text { wO } & & \\ \text { landbouw } & 5.988 & 700 \\ \text { techniek } & 337 & 2.100 \\ \text { economie } & 1.019 & 2.000 \\ \text { gezondheidszorg } & 967 & 1.500 \\ \text { gedrag en maatschappij } & 754 & 2.200 \\ \text { taal en cultuur } & 1.090 & 1.400 \\ \text { recht en openbare orde } & 701 & 1.500 \\ \text { natuurwetenschappen } & 733 & 800 \\ & 387 & \end{array}$

\section{Dekkingsgraad en respons}

De schoolverlaters die uiteindelijk in het onderzoeksbestand zijn opgenomen, vormen slechts een gedeelte van de gehele onderzoekspopulatie. Enerzijds worden niet álle personen uit de doelgroep benaderd en anderzijds reageert niet iedereen die wél is benaderd. De dekkingsgraad geeft een beeld van de omvang van het gedeelte van de populatie dat benaderd is. Het responspercentage geeft vervolgens aan welk deel van degenen die benaderd zijn daadwerkelijk heeft gereageerd.

\section{Dekkingsgraad}

Tabel 5.1 laat voor 1999 zien hoe groot de dekkingsgraad per onderwijssoort is. Uit de tabel blijkt dat er tussen de onderwijssoorten een groot verschil in dekkingsgraad bestaat. De dekkingsgraad bij zowel het AVO als het (I)VBO is laag, maar gestegen ten opzichte van verleden jaar (respectievelijk $8 \%$ en $9 \%$ ). Ook BOL niveau 1/2 laat een stijging van de dekkingsgraad zien ten opzichte van 1998 (29\% in 1999 ten opzichte van 21\% in 1998). Bij het

5. De aantallen van het WO hebben betrekking op 9 universiteiten. 
HBO is er wederom sprake van een hoge deelname. Hier wordt een dekkingsgraad van $75 \%$ bereikt, iets hoger dan in 1998 (73\%). De dekkingsgraad van HBO Kunst en Cultuur kan niet worden weergegeven, omdat de populatiegegevens gelijk zijn aan het aantal uitgezette vragenlijsten (zie paragraaf 3). Bij het WO zijn de cijfers over de dekkingsgraad niet weergegeven, omdat de gegevens voor de bepaling van de dekkingsgraad ontbreken voor de vier universiteiten die de WO-Monitor zelf uitvoeren.

Tabel 5.1

Dekkingsgraad per onderwijssoort, 1999

Onderwijssoort

$\begin{array}{cc}\text { Benaderd } & \text { Dekking } \\ \text { aantal } & \%\end{array}$

\begin{tabular}{|c|c|c|}
\hline AVO & 11.784 & 12 \\
\hline MAVO & 4.692 & 11 \\
\hline HAVO & 4.197 & 14 \\
\hline VWO & 2.895 & 12 \\
\hline VBO & 6.367 & 15 \\
\hline IVBO & 1.372 & 15 \\
\hline landbouw & 1.929 & 52 \\
\hline techniek & 1.372 & 9 \\
\hline economie & 804 & 15 \\
\hline gezondheidszorg & 935 & 9 \\
\hline BOL niveau $1 / 2$ & 3.300 & 29 \\
\hline landbouw & 173 & 53 \\
\hline techniek & 723 & 27 \\
\hline economie & 2.038 & 31 \\
\hline gezondheidszorg & 366 & 22 \\
\hline BOL niveau 3/4 & 15.213 & 36 \\
\hline landbouw & 1.564 & 48 \\
\hline techniek & 4.028 & 40 \\
\hline economie & 4.767 & 32 \\
\hline gezondheidszorg & 2.095 & 33 \\
\hline gedrag en maatschappij & 2.759 & 36 \\
\hline BBL niveau $1 / 2$ & 3.192 & 2 \\
\hline techniek & 1.516 & 18 \\
\hline economie & 1.460 & 26 \\
\hline gezondheidszorg & 216 & 20 \\
\hline
\end{tabular}

gezondheidszorg 
Tabel 5.1 (vervolg)

Dekkingsgraad per onderwijssoort, 1999

\begin{tabular}{lrc}
\hline Onderwijssoort & $\begin{array}{c}\text { Benaderd } \\
\text { aantal }\end{array}$ & $\begin{array}{c}\text { Dekking } \\
\%\end{array}$ \\
\hline BBL niveau 3/4 & 2.559 & 20 \\
techniek & 1.186 & 23 \\
economie & 979 & 50 \\
gezondheidszorg & 336 & 6 \\
gedrag en maatschappij & 58 & 8 \\
& & 75 \\
HBO & 36.091 & 95 \\
landbouw & 1.548 & 50 \\
onderwijs & 5.419 & 79 \\
techniek & 8.034 & 80 \\
economie & 10.646 & 85 \\
gezondheidszorg & 4.301 & 83 \\
gedrag en maatschappij & 6.143 & \\
\hline
\end{tabular}

\section{Respons}

Zoals uit tabel 5.2 blijkt is de respons ${ }^{7}$ het hoogst bij de schoolverlaters van het AVO (53\%). Het VBO volgt met $50 \%$. De respons van BBL niveau $1 / 2$ is het laagst, namelijk $30 \%$. Ten opzichte van het afgelopen jaar is de respons bij alle opleidingssectoren gedaald. Wat verder opvalt is dat er binnen iedere onderwijssoort sprake is van een vrij grote spreiding in de responspercentages. Met name bij BBL niveau 3/4 en WO zijn de verschillen tussen opleidingssectoren groot.

Door middel van een responsanalyse is geprobeerd een beter inzicht te krijgen in de factoren die van invloed zijn op de respons. Aangezien er (per definitie) vrij weinig gegevens bekend zijn over de schoolverlaters die niet gerespondeerd hebben, is de responsanalyse noodzakelijkerwijs beperkt. Er is informatie aanwezig over drie factoren die mogelijk invloed hebben op de respons. Ten eerste is informatie over de gevolgde opleiding van de aangeschreven schoolverlaters aanwezig. Ten tweede is de wijze van verzending van de vragenlijsten bekend. De vragenlijsten kunnen enerzijds centraal door DESAN aan de schoolverlaters worden toegestuurd; anderzijds kunnen de onderwijsinstellingen de vragenlijsten zelf verzenden. Dit laatste noemen we decentrale verzending. Ten derde is de regioverdeling in de steekproef bekend.

Wellicht geldt dat het responspercentage in de ene regio hoger ligt dan in de andere. Wanneer een bepaalde regio in de loop der jaren een steeds belangrijkere rol is gaan vervullen in de steekproef en als de respons tussen regio's inderdaad verschilt, dan kan dit een verklaring zijn voor veranderingen in de totale respons. Een soortgelijke situatie kan natuurlijk ook gelden voor het opleidingsniveau dat schoolverlaters hebben voltooid. Met behulp van logistische regressie-

6. Exclusief HBO Kunst en Cultuur.

7. Voor de berekeningswijze van de respons zie Willems en Van der Linden (1998). 
analyse is nagegaan wat de invloed is van deze drie factoren op de respons. De resultaten van deze analyse staan weergegeven in tabel 5.3.

Tabel 5.2

Responspercentage per opleidingssector, 1999

Opleidingssector

$\begin{array}{lr}\text { AVO } & 53 \\ \text { MAVO } & 51 \\ \text { HAVO } & 53 \\ \text { VWO } & 58 \\ & \\ \text { VBO } & 50 \\ \text { IVBO } & 52 \\ \text { landbouw } & 55 \\ \text { techniek } & 41 \\ \text { economie } & 47 \\ \text { gezondheidszorg } & 51\end{array}$

BOL niveau $1 / 2$

landbouw $\quad 45$

techniek $\quad 28$

economie 31

gezondheidszorg 41

BOL niveau 3/4

landbouw $\quad 55$

techniek 45

economie 44

gezondheidszorg 52

gedrag en maatschappij $\quad 50$

BBL niveau $1 / 2 \quad 30$

techniek 31

economie 26

gezondheidszorg $\quad 45$

BBL niveau 3/4 34

techniek 31

economie 31

gezondheidszorg $\quad 45$

gedrag en maatschappij $\quad 60$

$H B O=45$

landbouw $\quad 54$

onderwijs $\quad 40$

techniek 41

economie $\quad 45$

gezondheidszorg $\quad 52$

gedrag en maatschappij $\quad 50$

kunst en cultuur $\quad 34$ 
Tabel 5.2 (vervolg)

Responspercentage per opleidingssector, 1999

Opleidingssector $\quad \%$

$\begin{array}{lr}W O^{8} & 46 \\ \text { landbouw } & 76 \\ \text { techniek } & 47 \\ \text { economie } & 41 \\ \text { gezondheidszorg } & 49 \\ \text { gedrag en maatschappij } & 49 \\ \text { taal en cultuur } & 47 \\ \text { recht en openbare orde } & 40 \\ \text { natuurwetenschappen } & 44\end{array}$

De analyse toont dat, gecorrigeerd voor regio en wijze van verzending, schoolverlaters van het AVO het vaakst responderen. De respons onder de schoolverlaters van BBL niveau $1 / 2$ is relatief gezien het laagst. Beide bevindingen bevestigen het beeld dat al in tabel 5.2 is aangetroffen. Verder blijkt dat de respons geografisch ongelijkmatig verdeeld is. Evenals de afgelopen jaren is met name de respons in het westen het laagst. Daarnaast blijkt dat decentraal verzenden een significant hogere respons oplevert ten opzichte van centrale verzending van vragenlijsten.

Tabel 5.4 geeft tot slot een overzicht van de aantallen in 1999 uitgezette en teruggestuurde vragenlijsten. Dit overzicht geeft bovendien de belangrijkste redenen weer waarom sommige teruggestuurde vragenlijsten niet geschikt zijn voor verwerking. De belangrijkste reden hiervoor is het ontbreken van een juist adres. Voor $4 \%$ van de aangeschrevenen is dit het geval. Onder overige redenen vallen onder andere mensen die geen opleiding hebben verlaten maar wel als dusdanig door de onderwijsinstelling waren opgegeven en afgestudeerden die onbereikbaar waren vanwege bijvoorbeeld een verblijf in het buitenland of ziekte.

Tabel 5.3

De invloed van het opleidingsniveau, de regio en de wijze van verzending op de respons: logit effecten

Onafhankelijke variabelen Parameter Standaardfout

Constante

$-0,09^{* *}$

0,02

Onderwijssoort:

AVO

$0,30 * * \quad 0,03$

VBO

$-0,19^{\star \star}$

0,03

BOL $1 / 2$

$-0,62^{* *}$

0,04

BOL $3 / 4$

BBL $1 / 2$

0,03
$-0,74^{* *}$

0,02

Tabel 5.3 (vervolg)

0,04

De invloed van het opleidingsniveau, de regio en de wijze van verzending op de respons: logit effecten

8. De gepresenteerde responspercentages hebben betrekking op 9 van de 13 universiteiten. 
$\mathrm{BBL} 3 / 4$

$-0,60^{\star \star}$

0,05

$\mathrm{HBO}$

$-0,08^{\star \star}$

0,02

WO

referentiecategorie

Regio:

noord

$0,03 \quad 0,03$

oost

$0,10^{\star *}$

0,02

west

$-0,16^{\star *}$

0,02

zuid

referentiecategorie

Decentrale verzending

$0,07^{\text {** }}$

0,02

$\mathrm{N}=95.277$

** significant op 1\%-niveau 
Tabel 5.4

Resultaat dataverzameling in aantallen per onderwijssoort

\begin{tabular}{|c|c|c|c|c|c|c|c|c|c|}
\hline & AVO & VBO & $\mathrm{BOL} 1 / 2$ & $\mathrm{BOL} 3 / 4$ & $\mathrm{BBL} 1 / 2$ & $\mathrm{BBL} 3 / 4$ & $\mathrm{HBO}$ & $\mathrm{WO}^{9}$ & Totaal \\
\hline Totaal benaderd & 11.784 & 6.367 & 3.300 & 15.213 & 3.192 & 2.559 & 38.637 & 13.749 & 94.801 \\
\hline Retour ontvangen & 6.581 & 3.380 & 1.283 & 7.785 & 1.182 & 1.058 & 20.188 & 6.932 & 48.389 \\
\hline - Waarvan geschikt voor verwerking & 5.847 & 2.860 & 944 & 6.945 & 803 & 699 & 17.306 & 6.054 & 41.458 \\
\hline - Waarvan niet geschikt voor verwerking: & & & & & & & & & \\
\hline - onbestelbaar retour & 234 & 169 & 112 & 483 & 131 & 133 & 1.803 & 525 & 3.590 \\
\hline - weigering: anonimiteit of andere reden & 3 & 5 & 7 & 14 & 1 & 0 & 25 & 6 & 61 \\
\hline - $\quad$ school-/studiejaar verkeerd & 294 & 273 & 69 & 186 & 102 & 123 & 677 & 229 & 1.953 \\
\hline - overige redenen & 203 & 73 & 151 & 157 & 145 & 103 & 377 & 118 & 1.327 \\
\hline
\end{tabular}

9. De gepresenteerde aantallen hebben betrekking op 9 van de 13 universiteiten. 


\section{Non-respons}

Zoals in de vorige paragraaf reeds is vermeld varieert het responspercentage tussen de $29 \%$ (BBL niveau 1/2) en 53\% (AVO). De resultaten zoals die beschreven staan in de landelijke rapporten en instellingsrapportages hebben betrekking op deze responsgroep. Om te achterhalen of de onderzoeksresultaten die gebaseerd zijn op de gegevens van deze responsgroep geen vertekening van de werkelijkheid vormen, is het van belang na te gaan of er sprake is van een selectieve (non-)respons. Het mag niet zo zijn dat de groep respondenten en de groep nonrespondenten op kenmerken van elkaar verschillen. Als bijvoorbeeld de schoolverlaters die werkloos zijn grotendeels weigeren aan de enquête deel te nemen ontstaat er wat betreft het kenmerk werkloosheid een verschil tussen de non-responsgroep en de responsgroep. Dit zal vervolgens leiden tot een onderschatting van het werkelijke werkloosheidspercentage, indien dit wordt berekend op basis van de gegevens van de responsgroep.

Eventuele selectiviteit van de (non-)respons kan worden nagegaan door op enkele belangrijke kenmerken de responsgroep met de non-responsgroep te vergelijken. Dit is op twee manieren mogelijk:

(1) door kenmerken van de responsgroep te vergelijken met kenmerken van de doelgroeppopulatie die reeds op basis van andere bronnen bekend zijn, of;

(2) door een aanvullend onderzoek te houden onder de non-responsgroep, waarbij over enkele kernvariabelen informatie wordt ingewonnen.

Ten behoeve van het schoolverlatersonderzoek is vooraf nauwelijks enige informatie over de populatie bekend behalve over de gevolgde opleiding, het geslacht van de schoolverlaters en de regio van de opleiding. Deze populatiegegevens worden reeds gebruikt om het onderzoeksbestand te wegen waardoor op deze punten een landelijk representatief beeld ontstaat zodat voor het nagaan van de mate van selectiviteit van de (non-)respons derhalve een nonresponsonderzoek noodzakelijk is.

De vraag is vervolgens over welke kenmerken van de non-responsgroep informatie verzameld dient te worden. Het antwoord wordt bepaald door het belang dat binnen het schoolverlatersonderzoek aan verschillende kenmerken wordt gehecht en de mate waarin verwacht mag worden dat de respons op deze punten selectief is. De bestemming oftewel de maatschap-pelijke positie van schoolverlaters na het verlaten van de opleiding kan beschouwd worden als één van de belangrijkste kernpunten in de schoolverlatersenquêtes. Bovendien zou juist op dit punt selectiviteit in de (non-)respons kunnen ontstaan. Evenals in voorgaande jaren is het nonresponsonderzoek voor het uitvoeringsjaar 1999 daarom vooral toegespitst op de bestemming van schoolverlaters.

Een ander belangrijk aspect binnen het schoolverlatersonderzoek omvat het onderzoek onder degenen die betaald werk verrichten. Daarom wordt in het non-responsonderzoek ook getoetst op eventuele selectiviteit in het antwoord op de vraag 'Heb je op dit moment (ook) betaald werk? (inclusief een betaalde bijbaan en/of een leer-arbeidsplaats)'.

Non-responsonderzoek 
Het non-responsonderzoek voor 1999 heeft evenals in afgelopen jaren plaatsgevonden aan de hand van een korte telefonische enquête. De steekproef is gestratificeerd naar onderwijssoort. Binnen een onderwijssoort worden over de verschillende opleidingssectoren aselect schoolverlaters getrokken die in eerste instantie de schriftelijke vragenlijst niet hebben geretourneerd. Dit heeft geleid tot 1.150 respondenten in het non-responsonderzoek. De opleidingssectoren HBO kunst en cultuur en HBO pedagogisch onderwijs vormen een uitzondering op deze steekproeftrekking: hier zijn de non-respondenten, zoals eerder is aangegeven, al telefonisch benaderd.

Voor het uitvoeren van het telefonisch onderzoek onder de non-respondenten is gebruik gemaakt van een tweetal verschillende vragenlijsten: één voor non-respondenten van $\mathrm{AVO} /(\mathrm{I}) \mathrm{VBO} / \mathrm{BOL} / \mathrm{BBL}$ en één voor non-respondenten van het $\mathrm{HBO}$ en het WO. Aan de hand van die lijsten is informatie verzameld over de gevolgde opleiding van de non-respondent, over de belangrijkste bezigheid op het moment van enquêteren en (indien van toepassing) over de huidige baan. Aan alle non-respondenten is tevens gevraagd naar de reden waarom men in eerste instantie niet heeft deelgenomen aan het onderzoek.

Tabel 6.1 laat per onderwijssoort zien wat de redenen van weigering door de non-respondenten zijn geweest. Hierbij gaat het dus om de non-respondenten die in eerste instantie niet hebben deelgenomen aan het onderzoek, maar wel aan de telefonische enquête. De belangrijkste reden waarom schoolverlaters de vragenlijst niet hebben ingevuld en teruggestuurd is dat het invullen ervan teveel tijd of moeite kost. Een tweede reden die vaak wordt genoemd is dat men het gewoon vergeten is om de vragenlijst in te vullen en/of op te sturen. Overigens moet worden bedacht dat er bij het telefonisch benaderen van de non-respondenten wederom non-respons optreedt. De belangrijkste reden voor deze tweede non-respons is dat de schoolverlaters zijn verhuisd of dat het telefoonnummer foutief is.

\section{Toets op selectiviteit}

Vervolgens kan worden nagegaan of de responsgroep en de groep die aanvankelijk niet op de schriftelijke enquête heeft gereageerd van elkaar verschillen voor wat betreft de kernvariabelen bestemming en betaald werk. De significantie van dit verschil wordt bepaald aan de hand van de toets van Fisher (zie bijvoorbeeld Van der Genugten, 1986: pp. 298-304). Voordat deze Fishertoets kan worden toegepast, is het echter noodzakelijk om enkele aanpassingen in de databestanden van zowel de non-responsgroep als de responsgroep door te voeren. Allereerst zijn de afgestudeerden van het kunstonderwijs en het hoger pedagogisch onderwijs die telefonisch gereageerd hebben, overgeheveld van de responsgroep naar de non-responsgroep. Voor onderzoeksdoeleinden behoren ze weliswaar tot de normale respons, maar gezien het feit dat ze de schriftelijke vragenlijst niet hebben geretourneerd, worden ze in het non-respons onderzoek beschouwd als non-respons. 
Tabel 6.1

Redenen van schoolverlaters om de schriftelijke vragenlijst niet in te vullen en terug te sturen in percentages per onderwijssoort

\begin{tabular}{|c|c|c|c|c|c|c|c|c|c|}
\hline Reden & $\begin{array}{c}\text { AVO } \\
\%\end{array}$ & $\begin{array}{l}\text { VBO } \\
\%\end{array}$ & $\begin{array}{c}\text { BOL } 1 / 2 \\
\%\end{array}$ & $\begin{array}{c}\text { BOL 3/4 } \\
\%\end{array}$ & $\begin{array}{c}\text { BBL 1/2 } \\
\%\end{array}$ & $\begin{array}{c}\text { BBL 3/4 } \\
\%\end{array}$ & $\begin{array}{c}\mathrm{HBO} \\
\%\end{array}$ & $\begin{array}{c}\text { WO } \\
\%\end{array}$ & $\begin{array}{c}\text { Totaal } \\
\%\end{array}$ \\
\hline Geen echte reden & 9 & 14 & 13 & 8 & 16 & 5 & 15 & 11 & 12 \\
\hline Vragenlijst nooit ontvangen & 15 & 13 & 9 & 7 & 15 & 14 & 13 & 16 & 13 \\
\hline Vragenlijst kwijtgeraakt & 1 & 2 & 2 & 3 & 4 & 1 & 4 & 3 & 3 \\
\hline Vergeten & 18 & 20 & 14 & 16 & 11 & 23 & 15 & 16 & 16 \\
\hline Geen interesse & 19 & 17 & 11 & 17 & 13 & 12 & 7 & 9 & 12 \\
\hline Invullen kost teveel tijd en/of moeite & 27 & 28 & 40 & 38 & 23 & 27 & 34 & 36 & 33 \\
\hline Bedenkingen bij anonimiteit en/of privacy & 0 & 1 & 1 & 0 & 4 & 3 & 5 & 1 & 2 \\
\hline Vragenlijst was niet op mij van toepassing & 1 & 2 & 4 & 5 & 4 & 7 & 2 & 6 & 4 \\
\hline Andere redenen & 9 & 4 & 6 & 6 & 13 & 9 & 4 & 4 & 6 \\
\hline
\end{tabular}


Verder is de verdeling naar opleidingssector verschillend tussen het responsbestand en het nonresponsbestand. Om hiervoor te corrigeren - en dus beide bestanden op dit punt vergelijkbaar te maken - is het responsbestand zodanig (opnieuw) gewogen dat de verdeling over de opleidingssectoren overeenkomt met die van het non-responsbestand ${ }^{10}$. Tabel 6.2 laat per onderwijssoort voor elke bestemmingscategorie het resultaat van de toets van Fisher zien. Voor de volledigheid is aangegeven hoe de bestemming van de non-responsgroep en de responsgroep er in aantallen en percentages uit ziet. De aantallen voor de responsgroep zijn daarbij, zoals gezegd, zodanig aangepast dat de verdeling van de schoolverlaters over de opleidingssectoren binnen de desbetreffende onderwijssoort gelijk is aan de verdeling binnen deze onderwijssoort in het nonresponsbestand ${ }^{11}$.

De aantallen in de twee kolommen vormen de basis voor het berekenen van de z-score. Wat opvalt in tabel 6.2 is dat met name op HBO-niveau veel significante verschillen zijn tussen de non-respons en de responsgroep. Dit valt gedeeltelijk te verklaren door de grote aantallen respondenten die zijn ondervraagd. Verder hebben zowel binnen het HBO als het VBO repondenten minder vaak betaald werk dan non-respondenten. Op BBL niveau 3/4 is dit precies andersom. Daarnaast geven binnen het AVO duidelijk meer schoolverlaters uit de responsgroep aan doorgestroomd te zijn naar een reguliere studie dan schoolverlaters uit de nonresponsgroep.

Tabel 6.2

Toets van Fisher op selectiviteit naar bestemming tussen respondenten en non-respondenten per onderwijssoort

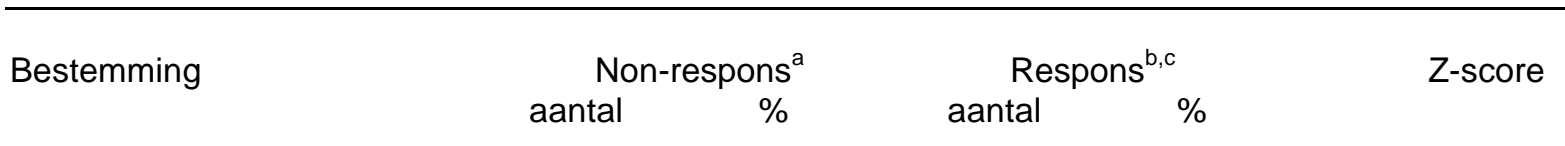

AVO
Ilw/ in-service
betaald werk
studie
werkloos
anders
VBO
Ilw/ in-service
betaald werk
studie
werkloos
anders

$\begin{array}{rr}5 & 6 \\ 20 & 23 \\ 64 & 72 \\ 0 & 0 \\ 0 & 0\end{array}$

$\begin{array}{rrl}62 & 3 & 1,36 \\ 215 & 11 & 3,52^{\star *} \\ 1.722 & 84 & -3,14^{\star *} \\ 8 & 0 & -0,59 \\ 33 & 2 & -1,21\end{array}$

10. In principe zou het ook mogelijk zijn geweest om het non-responsbestand te herwegen naar het (al dan niet gewogen) responsbestand. Aangezien het non-responsbestand sterk scheef verdeeld is over de opleidingssectoren, zou dit leiden tot zeer hoge en dus onbetrouwbare weegfactoren.

11. Uiteraard zou men de verdelingen nog meer op elkaar kunnen afstemmen door bijvoorbeeld ook rekening te houden met het kenmerk geslacht. Dit is echter niet gedaan, omdat de aantallen in het nonresponsbestand daarvoor te klein zijn. 
Tabel 6.2 (vervolg)

Toets van Fisher op selectiviteit naar bestemming tussen respondenten en non-respondenten per onderwijssoort

\begin{tabular}{|c|c|c|c|c|c|}
\hline \multirow[t]{2}{*}{ Bestemming } & \multicolumn{2}{|c|}{ Non-respons $^{\mathrm{a}}$} & \multicolumn{2}{|c|}{ Respons $^{b, c}$} & \multirow[t]{2}{*}{ Z-score } \\
\hline & aantal & $\%$ & aantal & $\%$ & \\
\hline \multicolumn{6}{|l|}{ BOL niveau $1 / 2$} \\
\hline Ilw/ in-service & 16 & 15 & 199 & 8 & $2,34^{*}$ \\
\hline betaald werk & 66 & 62 & 1.448 & 61 & 0,07 \\
\hline studie & 20 & 19 & 579 & 25 & $-1,38$ \\
\hline werkloos & 2 & 2 & 51 & 2 & $-0,20$ \\
\hline anders & 3 & 3 & 83 & 4 & $-0,39$ \\
\hline \multicolumn{6}{|l|}{ BOL niveau $3 / 4$} \\
\hline Ilw/ in-service & 6 & 5 & 54 & 2 & $2,16^{\star}$ \\
\hline betaald werk & 85 & 68 & 1.646 & 60 & 1,76 \\
\hline studie & 32 & 25 & 969 & 35 & $-2,23^{*}$ \\
\hline werkloos & 2 & 2 & 25 & 1 & 0,78 \\
\hline anders & 1 & 1 & 68 & 3 & $-1,20$ \\
\hline \multicolumn{6}{|l|}{ BBL niveau $1 / 2$} \\
\hline$\| w /$ in-service & 7 & 8 & 60 & 5 & 1,61 \\
\hline betaald werk & 73 & 88 & 1.138 & 86 & 0,42 \\
\hline studie & 1 & 1 & 45 & 3 & $-1,10$ \\
\hline werkloos & 1 & 1 & 20 & 2 & $-0,23$ \\
\hline anders & 1 & 1 & 55 & 4 & $-1,34$ \\
\hline \multicolumn{6}{|l|}{ BBL niveau 3/4 } \\
\hline Ilw/ in-service & 5 & 5 & 56 & 3 & 1,04 \\
\hline betaald werk & 80 & 83 & 1.574 & 90 & $-2,40^{*}$ \\
\hline studie & 9 & 9 & 33 & 2 & $4,75^{\star \star}$ \\
\hline werkloos & 2 & 2 & 23 & 1 & 0,62 \\
\hline anders & 1 & 1 & 61 & 4 & $-1,31$ \\
\hline \multicolumn{6}{|l|}{$\mathrm{HBO}$} \\
\hline betaald werk & 819 & 90 & 22.776 & 85 & $3,99^{\star *}$ \\
\hline studie & 67 & 7 & 2.773 & 10 & $-2,94^{\star *}$ \\
\hline werkloos & 12 & 1 & 447 & 2 & $-0,82$ \\
\hline anders & 15 & 2 & 791 & 3 & $-2,51^{*}$ \\
\hline \multicolumn{6}{|l|}{$w O^{12}$} \\
\hline betaald werk & 244 & 92 & 2.988 & 93 & $-1,22$ \\
\hline studie & 7 & 3 & 89 & 3 & $-0,19$ \\
\hline werkloos & 9 & 3 & 54 & 2 & $5,93^{\star *}$ \\
\hline anders & 5 & 2 & 80 & 3 & $-1,59$ \\
\hline
\end{tabular}

a. Inclusief telefonische respons (kunst- en pedagogisch onderwijs)

b. Exclusief telefonische respons (kunst- en pedagogisch onderwijs)

c. Gewogen naar de verdeling over de opleidingssectoren in het non-responsbestand. De hier gepresenteerde aantallen wijken derhalve af van de in de (landelijke) rapportages genoemde aantallen

* Significant op 5\%-niveau

** Significant op $1 \%$-niveau

12. De resultaten hebben betrekking op 9 van de 13 universiteiten. 
Tabel 6.3

Toets van Fisher op selectiviteit in het aandeel betaald werkende respondenten en het aandeel betaald werkende non-respondenten per onderwijssoort

\begin{tabular}{|c|c|c|c|}
\hline Betaald werk & Non-respons ${ }^{a}$ & Respons $^{\mathrm{b}, \mathrm{c}}$ & Z-score \\
\hline & aantal $\%$ & aantal $\%$ & \\
\hline
\end{tabular}

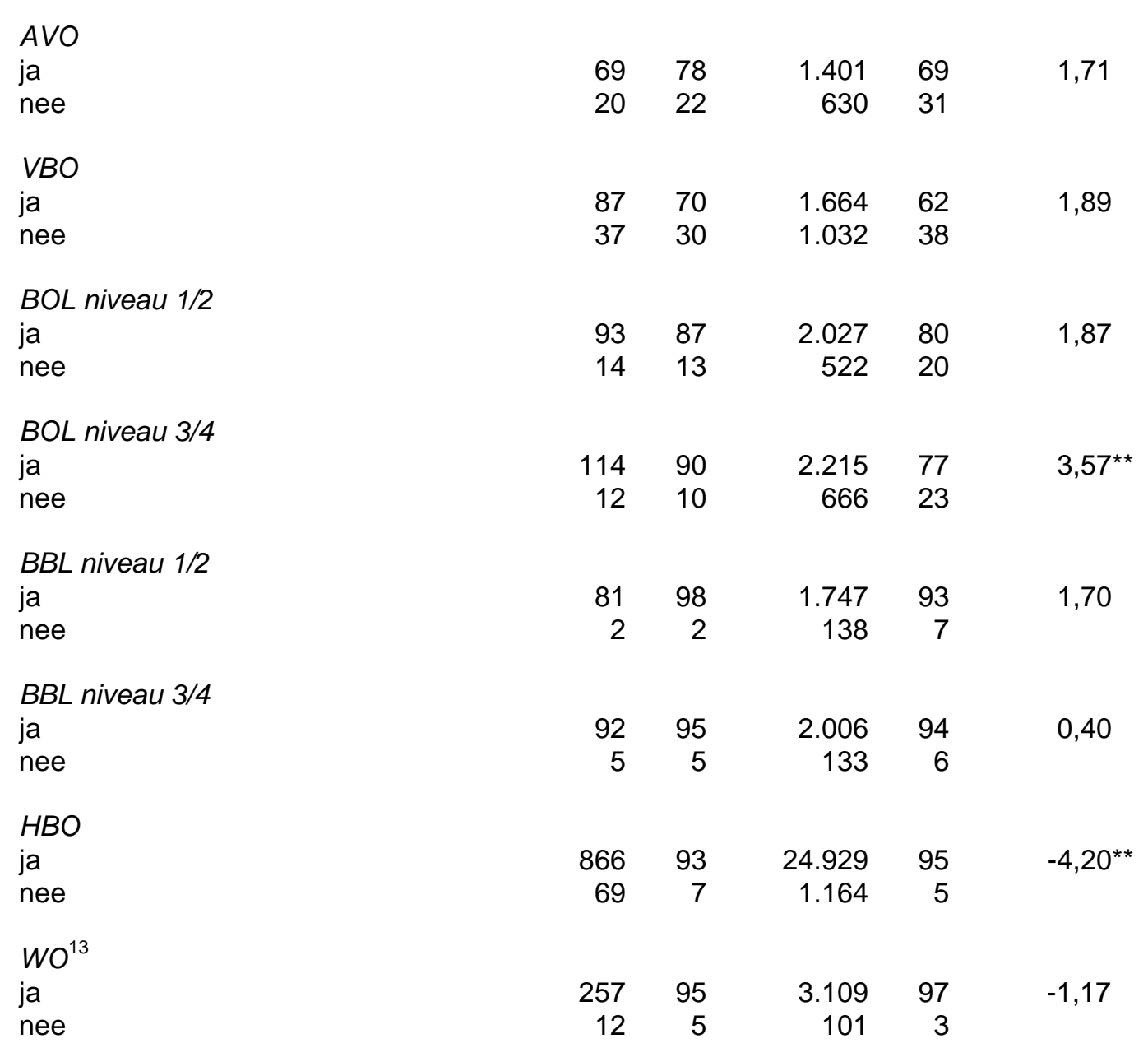

a. Inclusief telefonische respons (kunst- en pedagogisch onderwijs)

b. Exclusief telefonische respons (kunst- en pedagogisch onderwijs)

c. Gewogen naar de verdeling over de opleidingssectoren in het non-responsbestand. De hier gepresenteerde aantallen wijken derhalve af van de in de (landelijke) rapportages genoemde aantallen.

** Significant op 1\%-niveau

Of er sprake is van selectiviteit tussen de respons en de non-responsgroep in het antwoord op de vraag 'Heb je op dit moment (ook) betaald werk? (inclusief een betaalde bijbaan en/of een leer-arbeidsplaats)' staat weergegeven in tabel 6.3. De term betaald werk in tabel 6.2 is overigens niet dezelfde als het aandeel betaald werkenden waarnaar in tabel 6.3 wordt gekeken.

13. De resultaten hebben betrekking op 9 van de 13 universiteiten. 
Tabel 6.2 heeft betrekking op de activiteit die respondenten als hun belangrijkste bezigheid ervaren, terwijl er in tabel 6.3 wordt gekeken of iemand betaald werk heeft of niet, ongeacht of men dit de belangrijkste bezigheid vindt. Uit tabel 6.3 wordt duidelijk dat de responsgroep bij de meeste opleidingsniveaus over een geringer aandeel respondenten met betaald werk beschikt. Voor BOL niveau 3/4 is dit verschil zelfs significant. Bij het $\mathrm{HBO}$ en het WO daarentegen heeft de responsgroep relatief meer respondenten met betaald werk dan de non-responsgroep.

\section{Besluit}

In dit werkdocument wordt de methodiek beschreven van het Schoolverlaters-informatiesysteem (SIS) dat door het ROA in 1999 is uitgevoerd. Naast een overzicht van de opzet van dit onderzoek, de gehanteerde classificaties en de uitgevoerde controles en toegepaste correcties op het databestand, is vooral ingegaan op de dekkingsgraad, de respons en op het non-responsonderzoek.

Uit het gepresenteerde overzicht van de dekkingsgraad blijkt dat het schoolverlatersonderzoek over het algemeen zeer grootschalig van opzet is. In het AVO is echter sprake van een lage dekkingsgraad (12\%). Ook in het VBO en op BBL (beide niveaus) is er sprake van een relatief lage dekkingsgraad. Hierbij dient echter vermeld te worden dan er binnen deze onderwijssoorten aanzienlijke verschillen tussen de sectoren zijn (met name de sector landbouw op VBO-niveau scoort aanzienlijk hoger). BOL niveau $1 / 2$ heeft een dekkingsgraad van 29\%; BOL niveau 3/4 heeft een dekkingsgraad van 36\%; HBO scoort hoog met $75 \%$.

Ten opzichte van 1998 is er een dalende tendens te zien in de responspercentages. Het AVO scoort met $53 \%$ het best (in 1998 was dit nog $60 \%$ ), op de voet gevolgd door het VBO met $50 \%$. De respons binnen het BBL niveau $1 / 2$ is het laagst (30\%); BOL niveau $1 / 2$ heeft een responspercentage van $32 \%$ en BBL niveau $3 / 434 \%$. Bij de overige onderwijssoorten ligt dit percentage rond de $45 \%$. Als naar regio wordt gekeken blijkt dat schoolverlaters uit de regio west het slechtst responderen. Een belangrijke vraag is verder of de (non-)respons selectief is. Dit

blijkt enigszins het geval te zijn. Toch kan geconcludeerd worden dat het uitgevoerde onderzoek een redelijk en betrouwbaar beeld geeft van de bestemming en arbeidsmarktpositie van schoolverlaters.

\section{Literatuur}

Ellström, P. (1998), The Many Meanings of Occupational Competence and Qualification, in: W. J. Nijhof, J.N. Streumer (eds), Key Qualifications in Work and Education, Kluwer Academic Publishers, pp. 39-50. Genugten, B.B. van der (1986), Inleiding tot de waarschijnlijkheidsrekening en mathematische Statistiek deel 1, Stenfert Kroese, Leiden-Antwerpen.

Straetmans, G. (1998), Toetsing van Competenties (Publicaties Voortgezet Onderwijs), CITO, Arnhem. Tribe, J. (1996), Core Skills: a Critical Examination, in: Educational Review, 48 (1), pp.13-27.

Willems, E.J.T.A., A.S.R. van der Linden (1998), Methodiek schoolverlatersinformatiesysteem 1996, ROAW-1998/1, Maastricht. 


\section{Appendix A: Kernvragenlijst}

Tabel A.1

Overzicht kernvragen Schoolverlatersinformatiesysteem

Variabele

Opmerking

Algemeen

Geslacht

Leeftijd

Allochtoon

Toestemming doorgeven gegevens aan school

Onderwijsloopbaan

Gevolgde opleiding

Voltijd- of deeltijdvariant van gevolgde opleiding

Begindatum gevolgde opleiding

Einddatum gevolgde opleiding

Diploma of certificaat behaald van gevolgde opleiding

Opnieuw kiezen van gevolgde opleiding

Hoogste vooropleiding

Vooropleiding voor hoogste vooropleiding

Vervolgopleiding

Voltijd- of deeltijdvariant van vervolgopleiding

Vervolgopleiding diploma/gestopt

Plaats van vervolgopleiding

Aansluiting vervolgopleiding op gevolgde opleiding

Cursus/bedrijfsopleiding

Cursus/bedrijfsopleiding totale duur

Cursus/bedrijfsopleiding aantal uren per week

$\mathrm{HBO} / \mathrm{WO}$

niet IVBO wel MBO/HBO/WO

MBO (beperkt)/HBO/WO

$\mathrm{MBO} / \mathrm{HBO} / \mathrm{WO}$

$\mathrm{HBO} / \mathrm{WO}$

$\mathrm{HBO} / \mathrm{WO}$

AVO/MBO

niet WO

niet voor AVO

$\mathrm{MBO} / \mathrm{HBO} / \mathrm{WO}$

$\mathrm{MBO} / \mathrm{HBO} / \mathrm{WO}$

Arbeidsmarktintrede

Maatschappelijke positie sinds schoolverlaten

Actief gezocht naar werk tijdens of na opleiding

Begin actief zoeken naar werk

MBO/HBO/WO

Betaald werk gewenst aantal uren

Betaald werk laatste 4 weken gezocht

Beschikbaar betaald werk

Reden niet beschikbaar voor betaald werk

Inschrijving arbeidsbureau

Huidige functie begindatum

Huidige functie werving

Huidige functie beroep SBC '92

Huidige functie branche SBI '93

Huidige functie personeelsomvang bedrijf

Huidige functie vestigingsplaats bedrijf

Huidige functie dienstverband

Huidige functie aanstelling

Huidige functie vereist opleidingsniveau volgens werkgever

Huidige functie vereist opleidingsniveau volgens schoolverlaters

Huidige functie vereiste opleidingsrichting volgens werkgever

Huidige functie vereiste opleidingsrichting volgens schoolverlater

Huidige functie leidinggeven

Huidige functie arbeidsuren per week

Huidige functie bruto maandinkomen

Huidige functie aansluiting met gevolgde opleiding

bij kunst zowel betaalde als

onbetaalde werkkringen

$\mathrm{MBO} / \mathrm{HBO} / \mathrm{WO}$

niet IVBO/(I)VBO groen en VAVO

niet AVO wel MBO/HBO

HAO en WO LUW

niet bij AVO

HAO en WO LUW

MBO (beperkt)/HBO/WO 
Tabel A. 1 (vervolg)

Overzicht kernvragen Schoolverlatersinformatiesysteem

$\begin{array}{ll}\text { Variabele } & \text { Opmerking }\end{array}$

Nevenfuncties

Nevenfuncties aantal uren per week

Opleiding-huidige functie: belang van kennis en technieken

Opleiding-huidige functie: belang van vaardigheden

Opleiding-huidige functie: belang van houdingsaspecten

Opleiding-huidige functie: aandacht voor kennis en technieken

Opleiding-huidige functie: aandacht voor vaardigheden

Opleiding-huidige functie: aandacht voor houdingsaspecten

$\mathrm{MBO} / \mathrm{HBO} / \mathrm{WO}$
$\mathrm{MBO} / \mathrm{HBO} / \mathrm{WO}$
$\mathrm{MBO}$ (beperkt)/HBO/WO
$\mathrm{MBO}$ (beperkt)/HBO/WO
$\mathrm{MBO}$ (beperkt)/HBO/WO
$\mathrm{MBO}$ (beperkt)/HBO/WO
$\mathrm{MBO}$ (beperkt)/HBO/WO
$\mathrm{MBO}$ (beperkt)/HBO/WO

$\mathrm{MBO} / \mathrm{HBO} / \mathrm{WO}$

MBO (beperkt)/HBO/WO

MBO (beperkt)/HBO/WO

$\mathrm{MBO}$ (beperkt)/HBO/WO

$\mathrm{MBO}$ (beperkt)/HBO/WO 